\title{
An Efficient and Versatile Method for Synthesis of 1,4-Dihydropyridines at Mild Reaction Conditions
}

\author{
VIJENDER GOEL, ANJU BAJWAN, SONU CHAUHAN and SHARDA GOEL* \\ Department of Chemistry, Maharshi Dayanand University, Rohtak-124001, Haryana, India \\ vkg108@gmail.com
}

Received 6 December 2017 / Accepted 20 December 2017

\begin{abstract}
Abstarct: A simple, efficient, versatile and convenient Hantzsch method for synthesis of 1,4-dihydropyridines using ethylacetoacetate, ammonium acetate and substituted arylaldehydes in the presence of tetrabutylammonium hydrogen sulfate (TBAHS) have been reported. Among the popular reported heterogenous solid catalysts, TBAHS has gained high popularity in organic synthesis due to its selectivity, inertness and thermal stability. The method offers advantages such as better yields, short reaction times, a simple work-up procedure, easy isolation of catalyst and reusability of catalyst for several runs.
\end{abstract}

Keywords: 1,4-Dihydropyridines, Hantzsch method, Green Chemistry, Tetrabutylammonium hydrogen sulfate, Solvent free synthesis

\section{Introduction}

Nowadays, researchers have focused much interest towards cleaner, environmentally benign and solvent-free synthetic procedures not only for laboratory synthesis but also in chemical industry. In the context of green chemistry, the development of new methodologies in organic synthesis involving multicomponent reactions (MCRs) have become a significant area of research in organic chemistry and so practical procedures in the absence of solvents and catalysts have been adopted for accomplishment of greener and cleaner synthesis ${ }^{1-4}$. As the typical representative of solvent-free reactions, the grinding technique has been widely used in organic synthesis ${ }^{5-7}$. Among heterocyclic compounds containing six membered ring, important constituents that are usually found in biologically active natural products and medicinal compounds are 1,4-dihydropyridines ${ }^{8-10}$. These 1,4 DHP's have bronchodilator, antiatherosclerotic, antitumor, vasodilator, geroprotective, hapatoprotective, antidiabetic, neuroprotective and platelet anti-aggregator activities ${ }^{11-13}$ in addition to acting as cerebral antiischemic agents in treatment of Alzeimers disease and as a chemosensitizer in tumor therapy ${ }^{14-15}$. Various cardiovascular drugs such as amlodipine, nifedipine, nicardipine and other related derivatives are dihydropyridyl compounds effective in treatment of hypertension ${ }^{16-17}$.

Due to these reasons, 1,4-DHP's have attracted the attention of chemists and hence synthesis of these compounds has been a great focus in organic chemistry. Since the Hantzsch 
synthesis of 1,4-DHP's more than a century ago involves the reaction of ethylacetoacetate with aldehydes and ammonia in acetic acid or in refluxing alcohol and a number of modified methods under improved conditions have been reported but they suffer from several drawbacks such as use of excess of organic solvent, refluxing conditions, moisture sensitiveness, highly toxic and expensive reagents, long reaction times, unsatisfactory yields, high temperature and harsh reaction conditions.

Keeping in view of above facts, it was thought worthwhile to develop an efficient and versatile method for synthesis of 1,4-DHP's. In this communication, substituted 1,4-dihydropyridines were synthesized under solvent free conditions involving multicomponent condensation of ethylacetoacetate, arylaldehydes and ammonium acetate in presence of tetrabutylammonium hydrogen sulfate (TBAHS). TBAHS is one of the few phase transfer catalysts that is solid and hence can be conveniently weighed and used for efficient synthesis of 1,4-DHP's.

\section{Experimental}

Chemicals were purchased from Fluka, $\mathrm{CDH}$ and Aldrich chemical companies. All the products were identified by comparison of their physical and spectral data with those of the authentic samples. Melting points were determined using an electrothermal apparatus and were uncorrected (Table 1). The progress of the reactions was monitored by thin layer chromatography (TLC) using silica gel plates. IR spectra ( $\mathrm{KBr}$ disc) were recorded on a Perkin Elmer FT-IR spectrometer and ${ }^{1} \mathrm{H}$ NMR spectra were obtained by Bruker 400 Ultrasheild (400 MHz) spectrometer using TMS as internal standard at $\delta=0.00$.

\section{General procedure for preparation of 1,4-dihydropyridines}

A mixture of ethylacetoacetate $(2 \mathrm{mmol})$, ammonium acetate $(1.5 \mathrm{mmol})$ and arylaldehyde $(1 \mathrm{mmol})$ in presence of TBAHS was taken in a $10 \mathrm{~mL}$ pyrex beaker, mixed well and stirred on magnetic stirrer at $70{ }^{\circ} \mathrm{C}$ for $55-90 \mathrm{~min}$. After completion of the reaction (monitored by TLC), the contents were cooled. The solid catalyst was removed by filtration, washed with ethanol and kept aside for reuse. The product was further purified by recrystallization from ethylacetate.

\section{Physical and spectroscopic data of compounds}

Diethyl-2,6-dimethyl-4-(4-chlorophenyl)-1,4-dihydropyridine-3,5-dicarboxylate (2a) IR $\left(\mathrm{cm}^{-1}\right): 3340,3108,1695 ;{ }^{1} \mathrm{H}$ NMR $\left(\mathrm{CDCl}_{3}\right): 1.15(\mathrm{t}, J=7.00 \mathrm{~Hz}, 6 \mathrm{H}), 2.10(\mathrm{~s}, 6 \mathrm{H}), 4.05$ $(\mathrm{q}, J=7.00 \mathrm{~Hz}, 4 \mathrm{H}), 5.05(\mathrm{~s}, 1 \mathrm{H}, \mathrm{CH}), 7.80(\mathrm{~d}, J=7.50 \mathrm{~Hz}, 2 \mathrm{H}), 7.05(\mathrm{~d}, J=7.50 \mathrm{~Hz}, 2 \mathrm{H})$ and 8.25 (bs, $1 \mathrm{H}, \mathrm{NH})$.

Diethyl-2,6-dimethyl-4-(2,4-dichlorophenyl)-1,4-dihydropyridine-3,5-dicarboxylate $(2 \boldsymbol{b})$

IR $\left(\mathrm{cm}^{-1}\right): 3332,3105,1685 ;{ }^{1} \mathrm{H}$ NMR $\left(\mathrm{CDCl}_{3}\right): 1.20(\mathrm{t}, J=7.00 \mathrm{~Hz}, 6 \mathrm{H}), 2.15(\mathrm{~s}, 6 \mathrm{H}), 4.05$ $(\mathrm{q}, J=7.00 \mathrm{~Hz}, 4 \mathrm{H}), 5.10(\mathrm{~s}, 1 \mathrm{H}, \mathrm{CH}), 6.85(\mathrm{~d}, J=7.50 \mathrm{~Hz}, 1 \mathrm{H}), 7.05(\mathrm{~d}, J=7.50 \mathrm{~Hz}, 1 \mathrm{H})$, $7.20(\mathrm{~m}, 1 \mathrm{H})$ and $8.20(\mathrm{bs}, 1 \mathrm{H}, \mathrm{NH})$.

Diethyl-2,6-dimethyl-4-(4-methylphenyl)-1,4-dihydropyridine-3,5-dicarboxylate (2c)

IR $\left(\mathrm{cm}^{-1}\right): 3350,3105,1690 ;{ }^{1} \mathrm{H}$ NMR $\left(\mathrm{CDCl}_{3}\right): 1.20(\mathrm{t}, J=7.00 \mathrm{~Hz}, 6 \mathrm{H}), 2.10(\mathrm{~s}, 6 \mathrm{H}), 2.35$ $(\mathrm{s}, 3 \mathrm{H}), 4.00(\mathrm{q}, J=7.00 \mathrm{~Hz}, 4 \mathrm{H}), 5.10(\mathrm{~s}, 1 \mathrm{H}, \mathrm{CH}), 6.80(\mathrm{~d}, J=7.50 \mathrm{~Hz}, 2 \mathrm{H}), 7.00(\mathrm{~d}, J=$ $7.50 \mathrm{~Hz}, 2 \mathrm{H})$ and $8.25(\mathrm{bs}, 1 \mathrm{H}, \mathrm{NH})$. 
Diethyl-2,6-dimethyl-4-(4-methoxyphenyl)-1,4-dihydropyridine-3,5-dicarboxylate (2d) IR $\left(\mathrm{cm}^{-1}\right): 3320,3100,1695 ;{ }^{1} \mathrm{H}$ NMR $\left(\mathrm{CDCl}_{3}\right): 1.15(\mathrm{t}, J=7.00 \mathrm{~Hz}, 6 \mathrm{H}), 2.10(\mathrm{~s}, 6 \mathrm{H}), 3.60$ $(\mathrm{s}, 3 \mathrm{H}), 4.05(\mathrm{q}, J=7.00 \mathrm{~Hz}, 4 \mathrm{H}), 5.10(\mathrm{~s}, 1 \mathrm{H}, \mathrm{CH}), 6.70(\mathrm{~d}, J=7.50 \mathrm{~Hz}, 2 \mathrm{H}), 6.90(\mathrm{~d}, J$ $=7.50 \mathrm{~Hz}, 2 \mathrm{H})$ and $8.20(\mathrm{bs}, 1 \mathrm{H}, \mathrm{NH})$.

Diethyl-2,6-dimethyl-4-(3,4-dimethoxyphenyl)-1,4-dihydropyridine-3,5-dicarboxylate $(2 \boldsymbol{e})$

IR $\left(\mathrm{cm}^{-1}\right): 3370,3100,1695 ;{ }^{1} \mathrm{H}$ NMR $\left(\mathrm{CDCl}_{3}\right): 1.20(\mathrm{t}, J=7.00 \mathrm{~Hz}, 6 \mathrm{H}), 2.10(\mathrm{~s}, 6 \mathrm{H})$, $3.60(\mathrm{~s}, 3 \mathrm{H}), 3.65(\mathrm{~s}, 3 \mathrm{H}), 4.10(\mathrm{q}, J=7.00 \mathrm{~Hz}, 4 \mathrm{H}), 5.10(\mathrm{~s}, 1 \mathrm{H}, \mathrm{CH}), 6.60(\mathrm{~d}, J=7.50 \mathrm{~Hz}$, $1 \mathrm{H}), 6.70(\mathrm{~m}, 1 \mathrm{H}), 6.85(\mathrm{~d}, J=7.50 \mathrm{~Hz}, 1 \mathrm{H})$ and $8.20(\mathrm{bs}, 1 \mathrm{H}, \mathrm{NH})$.

Diethyl-2,6-dimethyl-4-(4-nitrophenyl)-1,4-dihydropyridine-3,5-dicarboxylate (2f)

IR $\left(\mathrm{cm}^{-1}\right): 3330,3085,1675 ;{ }^{1} \mathrm{H}$ NMR $\left(\mathrm{CDCl}_{3}\right): 1.20(\mathrm{t}, J=7.00 \mathrm{~Hz}, 6 \mathrm{H}), 2.15(\mathrm{~s}, 6 \mathrm{H}), 4.10$ $(\mathrm{q}, J=7.00 \mathrm{~Hz}, 4 \mathrm{H}), 5.10(\mathrm{~s}, 1 \mathrm{H}, \mathrm{CH}), 6.65(\mathrm{~d}, J=7.50 \mathrm{~Hz}, 2 \mathrm{H}), 7.00(\mathrm{~d}, J=7.50 \mathrm{~Hz}, 2 \mathrm{H})$ and $8.20(\mathrm{bs}, 1 \mathrm{H}, \mathrm{NH})$.

Diethyl-2,6-dimethyl-4-(4-bromophenyl)-1,4-dihydropyridine-3,5-dicarboxylate (2g)

IR $\left(\mathrm{cm}^{-1}\right): 3335,3090,1685 ;{ }^{1} \mathrm{H}$ NMR $\left(\mathrm{CDCl}_{3}\right): 1.15(\mathrm{t}, J=7.00 \mathrm{~Hz}, 6 \mathrm{H}), 2.10(\mathrm{~s}, 6 \mathrm{H}), 4.10$ $(\mathrm{q}, J=7.00 \mathrm{~Hz}, 4 \mathrm{H}), 5.05(\mathrm{~s}, 1 \mathrm{H}, \mathrm{CH}), 6.65(\mathrm{~d}, J=7.50 \mathrm{~Hz}, 2 \mathrm{H}), 7.00(\mathrm{~d}, J=7.50 \mathrm{~Hz}, 2 \mathrm{H})$ and 8.25 (bs, 1H, NH).

\section{Results and Discussion}

First, in order to optimize the conditions, the investigation was initiated with the condensation of ethylacetocetate, ammonium acetate and substituted arylaldehydes in the presence of TBAHS at $70{ }^{\circ} \mathrm{C}$ in 2:1.5:1 ratio under solvent free conditions as outlined below (Scheme 1).

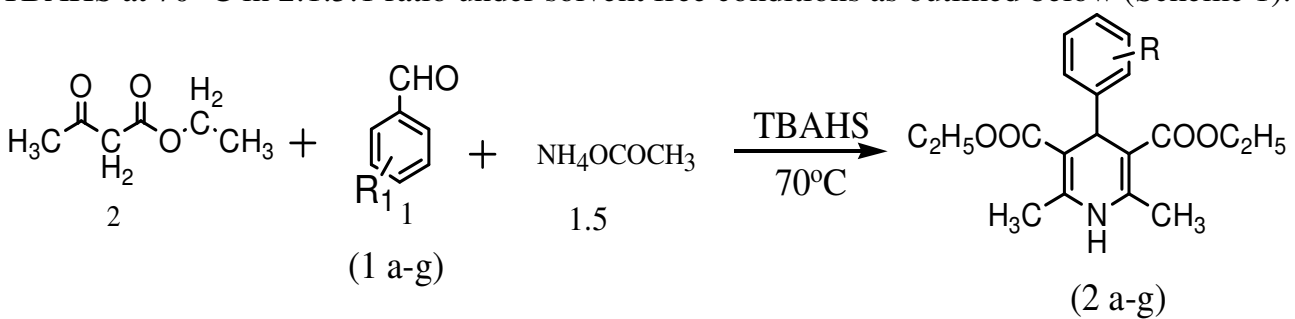

Scheme 1. Reaction scheme

The high catalytic activity of tetrabutylammonium hydrogen sulfate, its selectivity, inertness and ease of separation from the reaction mixture, renders it a very attractive catalyst over homogenous catalysts. The amount of the catalyst was varied to see the effect on the yield of product in the reaction. The optimum result was obtained when 150 $\mathrm{mg}$ of the catalyst was used. On increasing the quantity of catalyst, no change in the yield of the product was observed and on reducing the quantity of catalyst, poor yield of the desired product was noticed. All the prepared products were characterized by spectral analysis, comparison of the melting points and TLC with the standard compounds prepared by reported methods. Present methodology is more simple, efficient and economic than previous ones and offers advantages such as short reaction times, higher yields, easy isolation of catalyst and simple work up procedure, when compared with conventional method as well as with other catalysts. 
Table 1. Results of synthesis of 1, 4-dihydropyridines in the presence of TBAHS

\begin{tabular}{llllc}
\hline Entry & Time, min & Yield \% & M.P, ${ }^{\circ} \mathrm{C}$ \\
\hline & & & & $142-144{ }^{\circ} \mathrm{C}$ \\
{$\left[144-14{ }^{\circ} \mathrm{C}\right]^{12}$}
\end{tabular}

\section{Conclusion}

A simple, straight forward and economical method has been described for synthesis of 1,4-dihydropyridines. This method offers advantages in terms of mild experimentation conditions, economic catalyst, good to excellent yields, short reaction times and easy isolation of products.

\section{Acknowledgment}

The authors are thankful to Head, Chemistry department, M D. University, Rohtak for providing necessary facilities. Prof. Sharda Goel is also thankful to University Grant Commission (UGC), Delhi for grant of SAP (No-540/17 DRS-1/2016). 


\section{References}

1. Istvan $\mathrm{T}$ and Anastas $\mathrm{P}$ T, Chem Rev., 2007, 107(6), 2167-2168; DOI:10.1021/cr0783784

2. Ranu B C, Deya S S and Hajra A, Green Chem., 2003, 5, 44-46; DOI:10.1039/B211238H

3. Halimehjani A Z, Pourshojaei Y and Saidi M R, Tetrahedron Lett., 2009, 50(1), 32-34; DOI:10.1016/j.tetlet.2008.10.063

4. Sainani J B, Shah A C and Arya V P, Indian J Chem., 1994, 33, 526.

5. Habib P M, Kavala V, Kuo C W, Raihan M J and Yao C F, Tetrahedron, 2010, 66(34), 7050-7056; DOI:10.1016/j.tet.2010.05.104

6. Heravi M M, Poormohammad N, Beheshtiha Y S and Baghernejad B, Synth Commun., 2011, 41, 579-582; DOI:10.1080/00397911003629440

7. Kumar A and Makrandi J K, Green Chem Lett Rev., 2011, 4(1), 87-89; DOI:10.1080/17518253.2010.502909

8. Godfraid T, Miller R and Wibo M, Pharmacol Rev., 1986, 38(4), 321-416.

9. Sausins A and Duburs G, Heterocycles, 1988, 27(1), 269-289; DOI:10.3987/REV-87-370

10. Palakshi Reddy B Rajesh K and Vijayakumar V, Arabian J Chem., 2015, 8(1), 138-141; DOI:10.1016/j.arabjc.2011.01.027

11. Poindexter G S, Bruce M A, Breitenbucher J G, Higgins M A, Sit S Y, Romin J L, Martin S W, Ward S A, Mcgovern R T, Clarke W and Russel J, Biorg Med Chem., 2004, 12(2), 507-521; DOI:10.1016/j.bmc.2003.10.016

12. Eharkar P S, Desai B, Gaveria H, Varu B, Loriya R, Naliapara Y, Shah A and Kulkarni V M, J Med Chem., 2002, 45(22), 4858-4867; DOI:10.1021/jm020217z

13. Klegeris A, Liutkevicius E, Mikalauskiene G, Duburs G, McGeer P L and Klusa V, Eur J Pharmacol., 2002, 441(3), 203-218; DOI:10.1016/S0014-2999(02)01262-1

14. Arash G C, Mohammad A Z, Maryam H, Hamid G, Mohsen N, Somaieh Y and Bahman T, J Braz Chem Soc., 2011, 22(3), 525-531; DOI:10.1590/S0103-50532011000300016

15. Debache A, Ghalem W, Boulcina R, Belfaitah A, Rhouati S and Carboni B, Tetrahedron Lett., 2009, 50(37), 5248-5251; DOI:10.1016/j.tetlet.2015.07.046

16. Sivamurugan V, Vinu A, Palanichamy M and Murugesan V, Heteroat Chem., 2006, 17, 267-271; DOI:10.1002/hc.20197

17. Peri R, Padmanabhan S, Rutledge A, Singh S and Triggle D J, J Med Chem., 2000, 43(15), 2906-2914; DOI:10.1021/jm000028

18. Mansoor S S, Aswin K, Logaiya K and Sudhan S P N, J King Saud Univ Sci., 2013, 25(3), 191-199; DOI:10.1016/j.jksus.2013.02.001

19. Visentin S, Rolando B, Novara M, Roussel C, Gasco A, Roberta Fruttero, Monica Novara, Emilio Carbone, Christian Roussel, Nicolas Vanthuyne J Med Chem., 2004, 47(10), 2688-2693; DOI:10.1021/jm031109v 